\title{
Sediment imprint of the severe 2002 summer flood in the Lehnmühle reservoir, eastern Erzgebirge [Germany]
}

\author{
Lucas Kämpf, Achim Brauer, Peter Dulski, Karl-Heinz Feger, Frank Jacob, Eckehard Klemt
}

How to cite:

Kämpf, L., Brauer, A., Dulski, P., Feger, K.-H., Jacob, F. \& Klemt, E. (2012): Sediment imprint of the severe 2002 summer flood in the Lehnmühle reservoir, eastern Erzgebirge (Germany). - E\&G Quaternary Science Journal, 61 (1): 3-15. DOI: 10.3285/eg.61.1.01

Abstract: A series of 18 short cores has been obtained from the Lehnmühle reservoir (operation since 1932) in eastern Erzgebirge (Ger-
many) in order to investigate the effects of the severe flood event in August 2002 on sedimentation by combining microfacies
and high resolution $\mu$-XRF scanning techniques. A distinct graded detrital layer, unique for the whole record, appears in almost
the entire reservoir basin, ranging in thickness from $33 \mathrm{~mm}$ at proximal sites close to the river inflow to 5 mm at distal sites.
The total sediment influx during this event was estimated to approximately 2,400 tons. Around two-thirds of the sediment was
deposited in the southern-central part of the basin (approx. $32 \%$ of the basin area) due to basin morphometry and proximity to
the inflow. An enhanced flux of fine silt and clays to areas near the dam was observed and is likely driven by a steady current
towards the dam. Occurrence of detrital material in a lateral bay reveals that sediment derived not only from the main inflow
but also from surface runoff through non-permanently water bearing stream channels around the reservoir.
In addition to the exceptional 2002 flood layer, 22 microscopically thin detrital layers were detected in the sediment cores, most
of them at the deepest core locations close to the main dam. A chronology of detrital layers was established by ${ }^{137} \mathrm{Cs}$ dating of
three core sequences and was transferred to other cores by detailed correlation based on four lithological markers. The com-
parison with instrumental data reveals that $64 \%$ of the total 22 flood events over the last three decades with a daily discharge $>$
$8 \mathrm{~m}^{3} \mathrm{~s}^{-1}$ of the main inflowing stream resulted in deposition of a layer of detrital material in the reservoir basin.

\section{Sedimenteintrag durch das Augusthochwasser 2002 in die Talsperre Lehnmühle [Osterzgebirge]}

Kurzfassung:

Anhand von 18 Kurzkernen aus der Talsperre Lehnmühle (Inbetriebnahme 1932) im Osterzgebirge (Deutschland) wurden mittels mikrofaziellen und hochauflösenden $\mu$-XRF Scanning Verfahren Auswirkungen des extremen Augusthochwassers 2002 auf den Sedimenteintrag untersucht. Fast über den gesamten Talsperrenboden hinweg wurde eine für die gesamte Sedimentsequenz einmalig markante detritische Lage detektiert, welche eine Mächtigkeit von $5 \mathrm{~mm}$ an der Staumauer bis $33 \mathrm{~mm}$ nahe dem Zufluss misst. Die eingetragene Sedimentmenge dieser Lage wird auf ca. 2.400 Tonnen geschätzt, wovon etwa zwei Drittel im südlich-zentralen Teil des Beckens (ca. 32 \% der Gesamtfläche) abgelagert wurden, begründet durch die Beckenmorphologie und die Lage zum Zufluss. Feine Silt- und Tonpartikel wurden dagegen vornehmlich weiter in Richtung Staumauer transportiert, forciert durch eine ständige Wasserströmung durch das Staubecken. Eine erhöhte Akkumulation von detritischem Material in einer seitlichen Bucht zeigt, dass Sedimente nicht nur durch den Hauptzufluss eingetragen wurden, sondern ebenfalls durch Oberflächenabfluss in nicht ständig wasserführenden Rinnen um die Talsperre herum.

Neben der markanten Lage des Jahres 2002, wurden 22 weitere, mikroskopisch dünne detritische Lagen in den Sedimentkernen nachgewiesen, die meisten im Profundalbereich nahe der Staumauer. Eine Chronologie der detritischen Lagen wurde an drei ${ }^{137} \mathrm{Cs}$ datierten Kernsequenzen erstellt und durch detaillierte Korrelation mittels vier lithologischer Marker auf die übrigen Kerne übertragen. Der Vergleich mit instrumentellen Abflussdaten des Hauptzuflusses zeigt, dass während der letzten drei Jahrzehnte $64 \%$ von insgesamt 22 Hochwasserereignissen mit einem Tagesabfluss $>8 \mathrm{~m}^{3} \mathrm{~s}^{-1}$ in die Ablagerung von detritischem Material resultierten.

Keywords: $\quad$ lake sediments, flood events, detrital layers, microfacies analysis, eastern Erzgebirge, water supply reservoir

Addresses of authors: L. Kämpf* , A. Brauer, P. Dulski, GFZ German Research Centre for Geosciences, Section 5.2 Climate Dynamics and Landscape Evolution, D-14473 Potsdam, Germany. K.-H. Feger, F. Jacob, Dresden University of Technology, Institute of Soil Science and Site Ecology, D- 01737 Tharandt, Germany. E. Klemt, Hochschule Ravensburg-Weingarten, University of Applied Sciences, D-88250 Weingarten, Germany. *Corresponding author: L. Kämpf, GFZ German Research Centre for Geosciences, Section 5.2 Climate Dynamics and Landscape Evolution, 14473 Potsdam, Germany. E-Mail: lucask@gfz-potsdam.de

\section{Introduction}

Establishing long flood time series from geoarchives has become a main issue of modern palaeoclimatic research (BAKer 2006, Chapron et al. 2005, Czymzik et al. 2010, ThORNDYCRAFT et al. 2003). Particularly valuable archives are lakes because they form ideal traps in the landscape, continuously recording land surface processes in the catchment including extreme events (BRAUER 2004, BRAUER \& Casanova 2001, Thorndycraft et al. 1998). Discrete flood-triggered sediment fluxes of detrital channel, bank and catchment material into lakes result in long chronologies of detrital event layers (e.g. CHAPRON et al. 2005, Czymzik et al. 2010, Støren et al. 2010). Comparisons with instrumental hydrological data have revealed that sediment flux is not linearly related to discharge strength and that even strong flood events can miss in the sediment records (LAmoureux 2000, Swierczynski et al. 2009). Sediment input to the lake can be minimized, for example due to wash out of river channel material by former floods (SCHIEFER et al. 2011) or by reduced erosion due to a dense vegetation cover or a frozen ground (CzymziK et al. 2010, Gilli et 


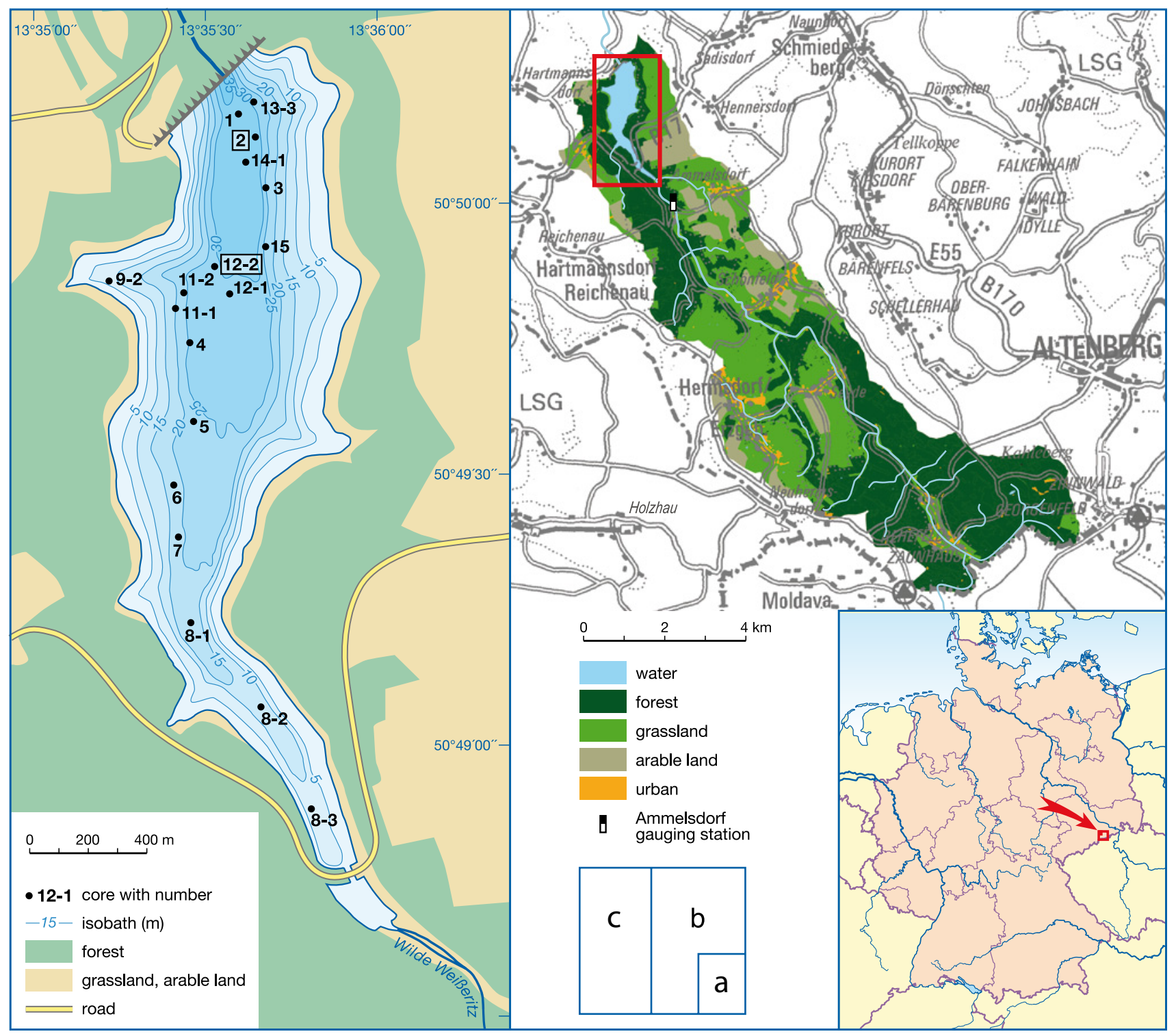

Fig. 1: Location of the Lehnmühle reservoir and the Wilde Weißeritz catchment in the eastern Erzgebirge. (a) Location within Germany. (b) Land use of the Weißeritz catchment, based on CIR-GIS data from 2005 and a topographic map 1: 50 000, supplied by LfULG. (c) Core locations within the reservoir (black dots); locations of master cores TSLM 2 and TSLM 12-2 are stressed.

Abb. 1: Talsperre Lehnmühle und Einzugsgebiet des Hauptzuflusses Wilde Weißeritz im Osterzgebirge. (a) Lage innerhalb Deutschlands. (b) Landnutzung im Einzugsgebiet der Wilden Weißeritz basierend auf CIR-GIS Daten (Stand: 2005) und topographischer Karte 1: 50 000, bereitgestellt vom LfULG. (c) Positionen der Sedimentkerne in der Talsperre (schwarze Punkte); hervorgehoben sind die Leitprofile TSLM 2 und TSLM 12-2.

al. 2003). Since sediment records often are obtained from a single location in the lake, missing detrital layers can also be caused by variability in sediment dispersion due to lake internal currents, stratification and basin morphometry (BEst et al., 2005, LAmB et al. 2010, Weirich 1986). Advancing the knowledge about the entire chain of sedimentary processes, leading to generation of detrital layers in lake sediments is crucial for improving their hydrological interpretation.

Besides natural lakes, reservoirs are suitable research objects, since in-depth monitoring provides a large variety of instrumental data, enabling a verification of sedimentological information (SHOTBOLt et al. 2005, SNYDER et al. 2006). Furthermore, flood events are of particular interest for reservoir management due to the consequences of an enhanced sediment delivery and the potential impact on water quality (DE CESARE et al. 2001, EFfLER et al. 2006). Therefore, this study aims to provide basic information about flood related sediment transport and deposition in a reservoir.

The main objective was to investigate the deposits of the severe 2002 summer flood in the Lehnmühle reservoir, located in eastern Erzgebirge (Germany). This flood occurred in the Elbe catchment and caused major damages (BfG 2002, LfULG 2004). It provides an ideal case study to investigate the impact of floods on sedimentation and to attempt to estimate total sediment flux into the reservoir during this single hydrometeorological event. It was a further objective to compare these deposits with the entire sediment record, formed since the operation started in 1932, to test if similar events have occurred in the past decades.

\section{Site description}

Lehnmühle reservoir was built from 1927 to 1931 in the upper eastern Erzgebirge (Germany), approx. $25 \mathrm{~km}$ south- 


\begin{tabular}{|c|c|}
\hline \multicolumn{2}{|l|}{ Lehnmühle reservoir } \\
\hline Built & 1927-1931 \\
\hline Reservoir volume & $23.73 \times 10^{6} \mathrm{~m}^{3}$ \\
\hline Dam water level & 522.2 ma.s.1. \\
\hline & 520.0 ma.s.1. in Aug 2008 (date of coring) \\
\hline Dam crest & 525.6 ma.s.1. \\
\hline Reservoir surface area & 135.0 ha \\
\hline Mean depth & $14.0 \mathrm{~m}$ \\
\hline Maximum depth & $35.6 \mathrm{~m}$ \\
\hline Trophy status & Mesotroph \\
\hline \multicolumn{2}{|l|}{ Open pre-dam } \\
\hline Height & $8 \mathrm{~m}$ \\
\hline Outlet diameter & $4 \mathrm{~m}$ \\
\hline \multicolumn{2}{|l|}{ Wilde Weißeritz } \\
\hline Mean discharge & $1.1 \mathrm{~m}^{3} \mathrm{~s}^{-1}$ \\
\hline Catchment size & $60.4 \mathrm{~km}^{2}$ (thereof $12.3 \mathrm{~km}^{2}$ in Czech Republic) \\
\hline Geology & $\begin{array}{c}\text { Gneiss }(60 \%) \text {, phyllite }(20 \%) \text {, felsic magmatites }(15 \%) \text {, } \\
\text { floodplain sediments }(5 \%)\end{array}$ \\
\hline Land use (German part) & $\begin{array}{c}\text { Forest }(62 \%) \text {, grassland }(18 \%) \text {, arable land }(13 \%) \text {, water } \\
\text { bodies }(2.2 \%) \text {, urban }(2.0 \%)\end{array}$ \\
\hline
\end{tabular}

Tab. 1: Characteristics of Lehnmühle reservoir and its tributary Wilde Weißeritz. Data from LTV (2002, 2009), LfULG.

Tab. 1: Daten zur Talsperre Lehnmühle und Hauptzufluss Wilde Weißeritz. Daten von LTV (2002, 2009), LfULG. east of Dresden (Fig. 1, Tab. 1). It is the upper of a chain of two reservoirs and was built (1) to reduce flood severity downstream and (2) to provide constant water supply for the downstream drinking water reservoir Klingenberg. In result of the latter, the water level of the Lehnmühle reservoir has been intensively regulated and underwent strong fluctuations. Even an almost complete emptying took place in autumn 1975, because of technical reasons (KAULFUSS 1979).

The reservoir is fed by the tributary Wilde Weißeritz, entering the main basin from the south after passing an open dam (Fig. 1c), consisting of a stone wall, approx. $8 \mathrm{~m}$ in height with an open gate at the center of the wall, which is around $4 \mathrm{~m}$ in diameter. The dam was built as traffic link and to trap sediments in a flat, approx. $400 \mathrm{~m}$ long basin in front of the open dam. Downstream of the reservoir the stream enters into the Elbe River in the city of Dresden. The watershed of the upper Wilde Weißeritz (Fig. 1b), feeding the reservoir with a long-term mean of $1.1 \mathrm{~m}^{3} \mathrm{~s}^{-1}$, covers $60.4 \mathrm{~km} 2$ and is characterized by smooth plateaus and steep hill slopes ranging from $522 \mathrm{~m}$ above sea level (a.s.l.) at the reservoir to $890 \mathrm{~m}$ a.s.l. at the main mountain crest. The land cover is mainly forest (62\%), grassland (18\%) and arable land (13\%), with forest dominating high altitude areas and left streambank areas next to the reservoir, respectively (LTV 2002). Dominant soils are poorly developed cambisols and podzols, which have developed from periglacial cover beds mainly above gneiss, phyllite and rhyolite (KAULFUSS 1979) and, thus, are characterized by dominance of siliciclastic minerals, mainly mica, quartz and feldspars. Annual mean precipitation ranges from approx. $880 \mathrm{~mm}$ at Lehnmühle reservoir to $1000 \mathrm{~mm}$ at high altitude areas of the catchment (KAULFUSS 1979, BERNHOFER et al. 2008). Maximum rainfall amounts are recorded in summer and are caused by instantaneous, often intense convective rainfall. A second maximum in winter relates to more persistent precipitation, often as snowfall, which is driven by westerlies (BERNHOFER et al. 2008). The latter is the reason for maximum mean discharges during the snow melt sea- son from March to April, attended by the highest flood frequency (Fig. 2). Additionally, intense discharges frequently occur in summer due to heavy short term precipitation, like in the case of the August 2002 flood (BERNHOFER et al. 2008).

\section{Methods}

In total, 18 short cores were taken from Lehnmühle reservoir in August 2008, using a Ghilardi Gravity Corer Type $\mathrm{KGH}$ 94. These cores were 13.5 to $62.0 \mathrm{~cm}$ long and have been collected in water depths between 8.8 and $33.0 \mathrm{~m}$ (Tab. 2). After cutting the cores into two halves, lithological description, digital photographs and magnetic susceptibility scanning on the split core surface (Barington MS2E Sensor) were carried out for each sediment core. The core sequences were correlated, using distinct lithological markers (Fig. 3), except the shallow water cores TSLM 8-2 and TSLM 8-3.

A series of cores from different parts of the basin has been selected for detailed microfacies analyses: TSLM 1 and TSLM 2 close to the dam, TSLM 12-1, TSLM 12-2 and TSLM 4 in the center of the basin as well as TSLM 6 and TSLM 7 in the southern proximal area closer to the river inflow (Fig. 1, Tab. 2). In addition, the uppermost 10 to 18 $\mathrm{cm}$ have been analyzed from most other cores (Tab. 2). Microfacies analyses have been carried out on large format thin sections. For this, overlapping samples $(10 \mathrm{~cm} \times 2 \mathrm{~cm}$ $\mathrm{x} 1 \mathrm{~cm}$ ) were taken from the fresh sediment surface of a split core half. The procedure of thin section preparation is described in detail by BRAUER \& CASANOvA (2001) and MANGILI et al. (2005). Analyses have been carried out under magnifications between $12.5 \mathrm{x}$ and $100 \mathrm{x}$, using a petrographic microscope (Carl Zeiss Axiophot). Thin-section images were obtained with a digital camera (Carl Zeiss Axiocam) and the software Carl Zeiss Axiovision 2.0.

In addition, high-resolution semi-quantitative geochemical data were obtained by micro X-ray fluorescence $(\mu-\mathrm{XRF})$ measurements on impregnated sediment slabs from thin section preparation of cores TSLM 2, TSLM 12-2 and from the upper $10 \mathrm{~cm}$ of core TSLM 12-1, allow- 


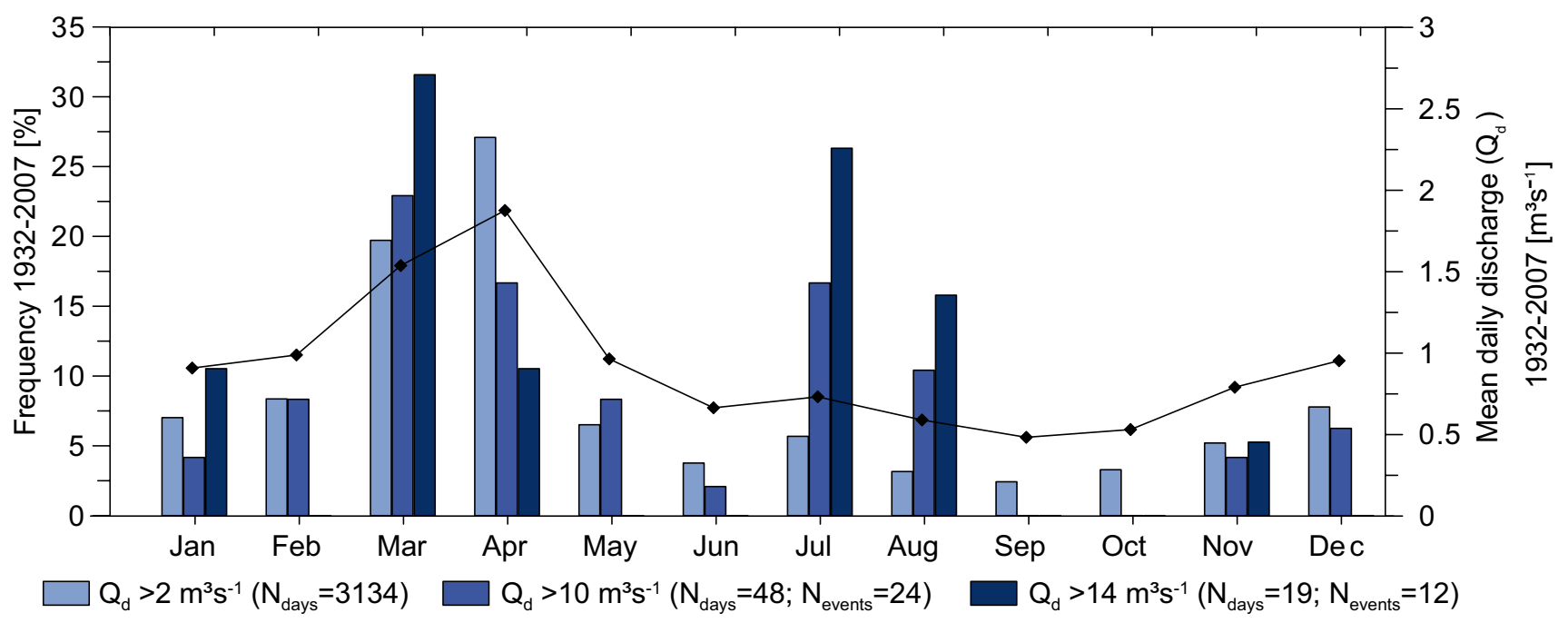

Fig. 2: Mean monthly discharge (line) and annual frequency distribution of Wilde Weißeritz discharge events of different intensities (bars), based on daily discharge values $(Q d)$, recorded at Ammelsdorf gauge station located approx. $1 \mathrm{~km}$ upstream of the inflow to Lehnmühle reservoir (11/01/1931 to 10/31/2007).

Abb. 2: Mittlerer monatlicher Abfluss (Linie) und jährliche Häufigkeitsverteilung von unterschiedlich starken Abflussereignissen der Wilden Weißeritz (Balken) basierend auf Tagesmittelwerten (Qd) vom Pegel Ammelsdorf, ca. 1 km vorm Eintritt des Flusses in die Talsperre (01.11.1931 bis 31.10.2007).

Tab. 2: List of 18 gravity cores, taken from Lehnmühle reservoir in August 2008 (water level: $520.0 \mathrm{~m}$ a.s.l.). Water level drawdown has led to exposure of coring locations (most recently notified). I/II trans. is the border between sediment units I and II. Age of each core basis (sediment unit II) refers either to the I/II transition (1932) or to correlated lithological markers. Underlined are the two dated master cores TSLM 2 close to the dam an TSLM 12-2 in the basin center.

Tab. 2: Liste der 18 Sedimentkerne aus der Talsperre Lehnmühle (entnommen im August 2008, Wasserstand: 520.0 m ü. NN). Exposure: 7üngstes Trockenfallen der Kernposition bei niedrigem Wasserstand. I/II trans.: Grenze zwischen Sedimenteinheiten I und II. Basis age: Das Alter der Kernbasis (Sedimenteneinheit II) bezieht sich entweder auf die I/II Grenze (1932) oder auf korrelierte lithologische Markerpunkte. Unterstrichen sind die zwei datierten Hauptprofile TSLM 2 am Hauptdamm und TSLM 12-2 in der Beckenmitte.

\begin{tabular}{|c|c|c|c|c|c|c|c|c|c|c|}
\hline $\begin{array}{l}\text { Name } \\
\text { TSLM }\end{array}$ & $\begin{array}{c}\text { Lat } \\
{\left[50^{\circ} \mathrm{N}\right]}\end{array}$ & $\begin{array}{c}\text { Lon } \\
{\left[13^{\circ} \mathrm{E}\right]}\end{array}$ & $\begin{array}{c}\begin{array}{c}\text { Water } \\
\text { depth } \\
{[\mathrm{m}]}\end{array} \\
\end{array}$ & $\begin{array}{c}\text { Exposure } \\
{[\mathrm{yr} A D]}\end{array}$ & $\begin{array}{c}\text { Core } \\
\text { length } \\
{[\mathrm{cm}]}\end{array}$ & $\begin{array}{c}\text { I/II trans. } \\
{[\mathrm{cm}]}\end{array}$ & $\begin{array}{c}\text { Basis age } \\
{[\mathrm{yr} \mathrm{AD}]}\end{array}$ & $\begin{array}{c}\text { Microfacies } \\
{[\mathrm{cm}]} \\
\end{array}$ & $\begin{array}{c}\boldsymbol{\mu} \text {-XRF } \\
{[\mathrm{cm}]} \\
\end{array}$ & $\begin{array}{r}{ }^{137} \mathbf{C s} \\
{[\mathrm{cm}]}\end{array}$ \\
\hline 1 & 49'58.9" & $35^{\prime} 36.1^{\prime \prime}$ & 33.0 & $(-)$ & 33.2 & $>33.2$ & $1932-1954$ & $0-33$ & & \\
\hline$\underline{2}$ & $49^{\prime} 56.6 "$ & $35^{\prime} 39.0^{\prime \prime}$ & 32.0 & $(-)$ & 30.5 & $>30.5$ & $1932-1954$ & $0-30.5$ & $0-30.5$ & $0-30.5$ \\
\hline$\overline{3}$ & 49'51.6" & $35^{\prime} 41.1^{\prime \prime}$ & 26.0 & 1975 & 23.2 & $>23.2$ & $1932-1987$ & $0-18$ & & \\
\hline 4 & 49'36.4" & $35^{\prime} 28.3^{\prime \prime}$ & 26.0 & 1975 & 51.0 & 25.2 & 1932 & $0-26$ & & \\
\hline 5 & $49 ' 28.6 "$ & $35^{\prime} 28.8^{\prime \prime}$ & 24.0 & 1976 & 53.4 & 25.0 & 1932 & $0-26$ & & \\
\hline 6 & 49'22.4" & $35^{\prime} 25.9^{\prime \prime}$ & 17.0 & 1980 & 37.3 & 19.5 & 1932 & $0-26$ & & \\
\hline 7 & 49'17.3" & $35^{\prime} 26.6^{\prime \prime}$ & 17.2 & 1980 & 35.0 & 19.8 & 1932 & $0-26$ & & $0-21$ \\
\hline $8-1$ & $49^{\prime} 8.8^{\prime \prime}$ & $35^{\prime} 29.0^{\prime \prime}$ & 17.5 & 1980 & 62.0 & unclear & & $0-18$ & & \\
\hline $8-2$ & $49^{\prime} 0.5^{\prime \prime}$ & $35^{\prime} 38.9^{\prime \prime}$ & 13.3 & 2003 & 34.5 & 28.0 & 1932 & - & & \\
\hline $8-3$ & $48^{\prime} 50.3^{\prime \prime}$ & $35^{\prime} 48.2^{\prime \prime}$ & 9.3 & 2003 & 13.5 & unclear & & - & & \\
\hline $9-2$ & $49^{\prime} 42.5^{\prime \prime}$ & $35^{\prime} 14.7^{\prime \prime}$ & 8.8 & 2003 & 33.8 & unclear & & $0-10$ & & \\
\hline 11-1 & 49'39.8" & $35^{\prime} 26.0^{\prime \prime}$ & 21.7 & 1976 & 32.8 & 21.0 & 1932 & $0-26$ & & \\
\hline $11-2$ & $49^{\prime} 41.3^{\prime \prime}$ & $35^{\prime} 27.4^{\prime \prime}$ & 23.8 & 1976 & 42.4 & 17.5 & 1932 & $0-10$ & & \\
\hline $12-1$ & $49^{\prime} 41.2^{\prime \prime}$ & $35^{\prime} 35.1^{\prime \prime}$ & 28.5 & 1975 & 46.2 & 25.2 & 1932 & $0-26$ & $0-10$ & \\
\hline $12-2$ & $49^{\prime} 43.9^{\prime \prime}$ & $35^{\prime} 31.8^{\prime \prime}$ & 29.0 & 1975 & 38.0 & 29.0 & 1932 & $0-34$ & $0-34$ & $0-30$ \\
\hline$\overline{13-1}$ & $50^{\prime} 00.0^{\prime \prime}$ & $35^{\prime} 38.8^{\prime \prime}$ & 29.0 & 1975 & 23.4 & $>23.4$ & $1932-1987$ & $0-10$ & & \\
\hline 14-1 & 49'54.1" & $35^{\prime} 37.3^{\prime \prime}$ & 31.0 & $(-)$ & 26.3 & $>26.3$ & $1932-1983$ & $0-10$ & & \\
\hline 15 & $49^{\prime} 45.8^{\prime \prime}$ & $35^{\prime} 41.2^{\prime \prime}$ & 24.1 & 1975 & 33.0 & 14.5 & 1932 & $0-10$ & & \\
\hline
\end{tabular}

ing direct comparison of geochemical and microfacies data (BrAuER et al. 2009). Micro-XRF scanning has been carried out using an EAGLE III XL $\mu$-XRF spectrometer with a low power Rh X-ray tube at $40 \mathrm{kV}$ and $300 \mu \mathrm{A}$. All measurements were performed under vacuum on a single scan line with $250 \mu \mathrm{m}$ spot size, $200 \mu \mathrm{m}$ step width and a counting time of $60 \mathrm{~s}$. The fluorescent radiation emitted from the sample was recorded by an energy dispersive $\mathrm{Si}(\mathrm{Li})$ detector and transformed into element information for each measuring point. Each data point reflects the mean element intensity, expressed in counts per second (cps).

For complementary bulk sediment analyses, volumetric samples were taken in $1 \mathrm{~cm}$ intervals from master cores TSLM 2 and TSLM 12-2. Samples were freeze dried and 


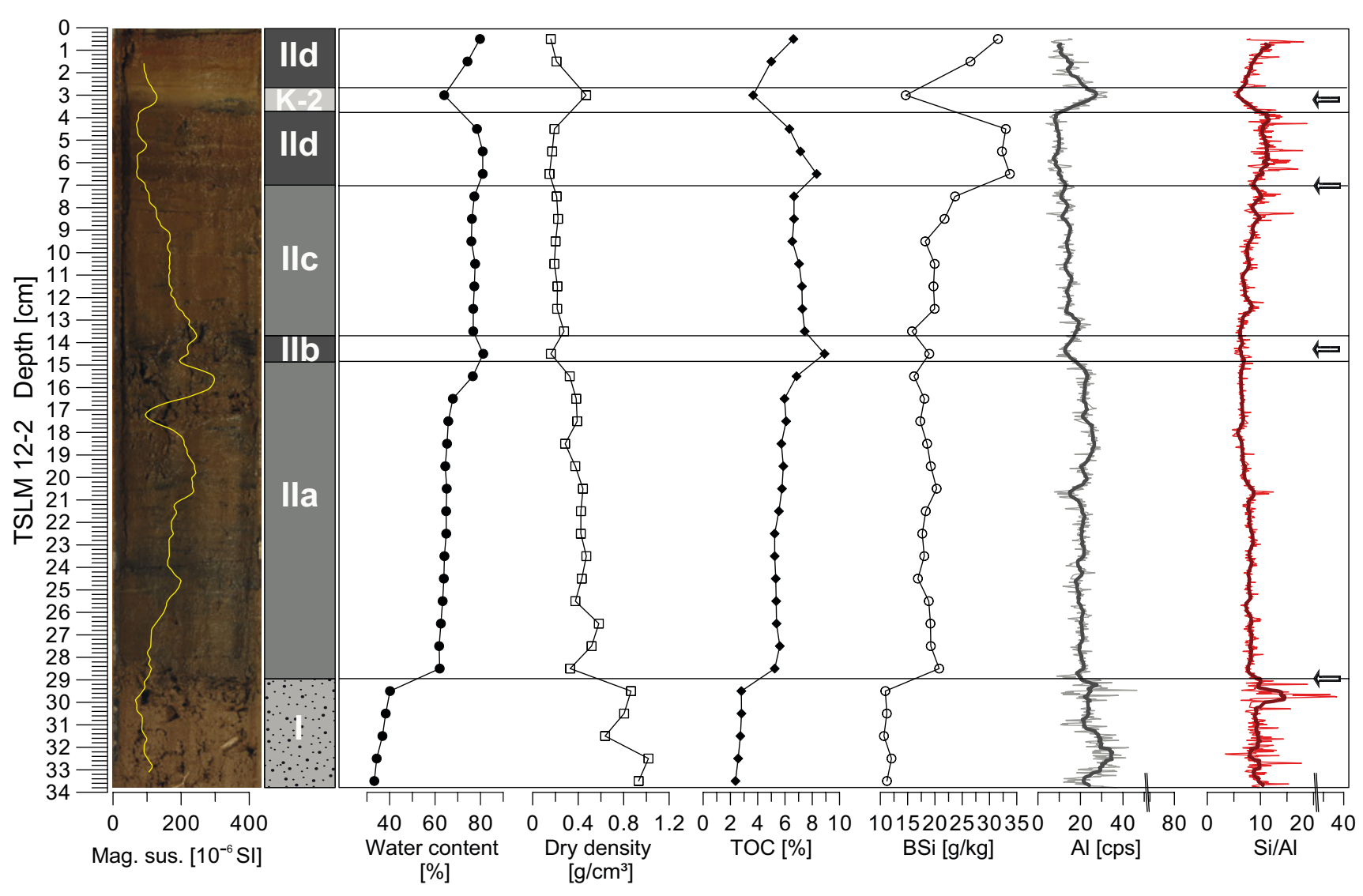

Fig. 3: Lithology of the master core sequence TSLM 12-2 from the basin center: core photo with magnetic susceptibility, water content, bulk density, contents of total organic carbon (TOC) and biogenic silica (BSi) and $\mu$-XRF values of aluminum (Al) and the silicon:aluminum ratio (Si/Al). Arrows mark the lithological markers used for core-to-core correlation.

Abb. 3: Lithologie des Leitprofils TSLM 12-2 (Beckenmitte): Kernfoto mit den Parametern magnetische Suszeptibilität (Mag. sus.), Wassergehalt (Water content), Dichte (Bulk density), Gehalte des organisches Kohlenstoffs (TOC) und des biogenen Siliziums (BSi) und $\mu$-XRF Werte von Aluminium (Al) und des Silizium:Aluminium Verhältnisses (Si/Al). Die Pfeile markieren die lithologischen Markerhorizonte für die Korrelation der Kernprofile.

their water contents were determined. Bulk density was calculated by dividing dry mass by volume of the sample (HÅKANSON \& JANSSON 1983). The most prominent detrital layer has been sub-sampled separately for calculating the accumulated sediment mass by multiplying bulk density with layer thickness as measured in thin sections.

Measurements of total organic carbon (TOC) were performed with an elemental analyzer Euro Vector EA (EuroEA 3000 Series). Sample preparation included homogenizing $3 \mathrm{mg}$ dried material, treatment with $3 \%$ and $20 \%$ $\mathrm{HCl}$ and further heating to $70{ }^{\circ} \mathrm{C}$. Biogenic silica (BSi) was extracted from the dried samples, following instructions of ENGSTROM \& WRIGHT (1984), modified by JACOB et al. (2009) and was determined, using a ICP-AES (CIROS, Spectro) at Dresden University of Technology.

The chronology has been established by measuring ${ }^{137} \mathrm{Cs}$ activity on homogenized samples from cores TSLM 2, TSLM 7 and TSLM 12-2, using a High Purity Germanium detector (well type) (Canberra-Eurysis) at Ravensburg-Weingarten University of Applied Sciences.

Runoff data of Wilde Weißeritz were used for interpretation of investigated sedimentological data and are based on mean daily discharge values, recorded at Ammelsdorf gauging station (Fig. 1). Data were supplied by the LfULG (Saxony State Office for the Environment, Agriculture and Geology). The gauging station was destroyed by water masses of the flood in August 2002 and data from this time derive from the LTV (The State Reservoir Administration of Saxony), calculated to daily means by water level change and withdrawal. No discharge data are available in the time periods November 1943 to October 1945 and November 1962 to October 1963. Daily water level data measured at the main dam of Lehnmühle reservoir since January $1^{\text {st }} 1962$ were supplied by the LTV.

\section{Results}

\subsection{Lithology}

In the sediment record from Lehnmühle reservoir two main lithological units (I and IIa-d) have been distinguished in 10 from 18 cores (Tab. 2, Fig. 3). The lowermost sediment unit I was found in cores TSLM 4, 5, 6, 7, 8-2, 11-1, 11-2, 12-1, 12-2 and 15 (Tab. 2) and is characterized by a light colored and poorly sorted sediment with grain sizes up to fine pebbles and abundance of roots and plant remains. High bulk density (around $1 \mathrm{~g} \mathrm{~cm}-3$ ) and low contents of water and total organic carbon (TOC) $(<3 \%)$ indicate high minerogenic contents. Sediment unit II is characterized by a generally higher content of organic matter and finer grain sizes, ranging from clay to coarse silt.

The sharp boundary between the two main units I and II (Fig. 3) is interpreted as the transition from the old land surface before the reservoir construction (unit I) to lacus- 


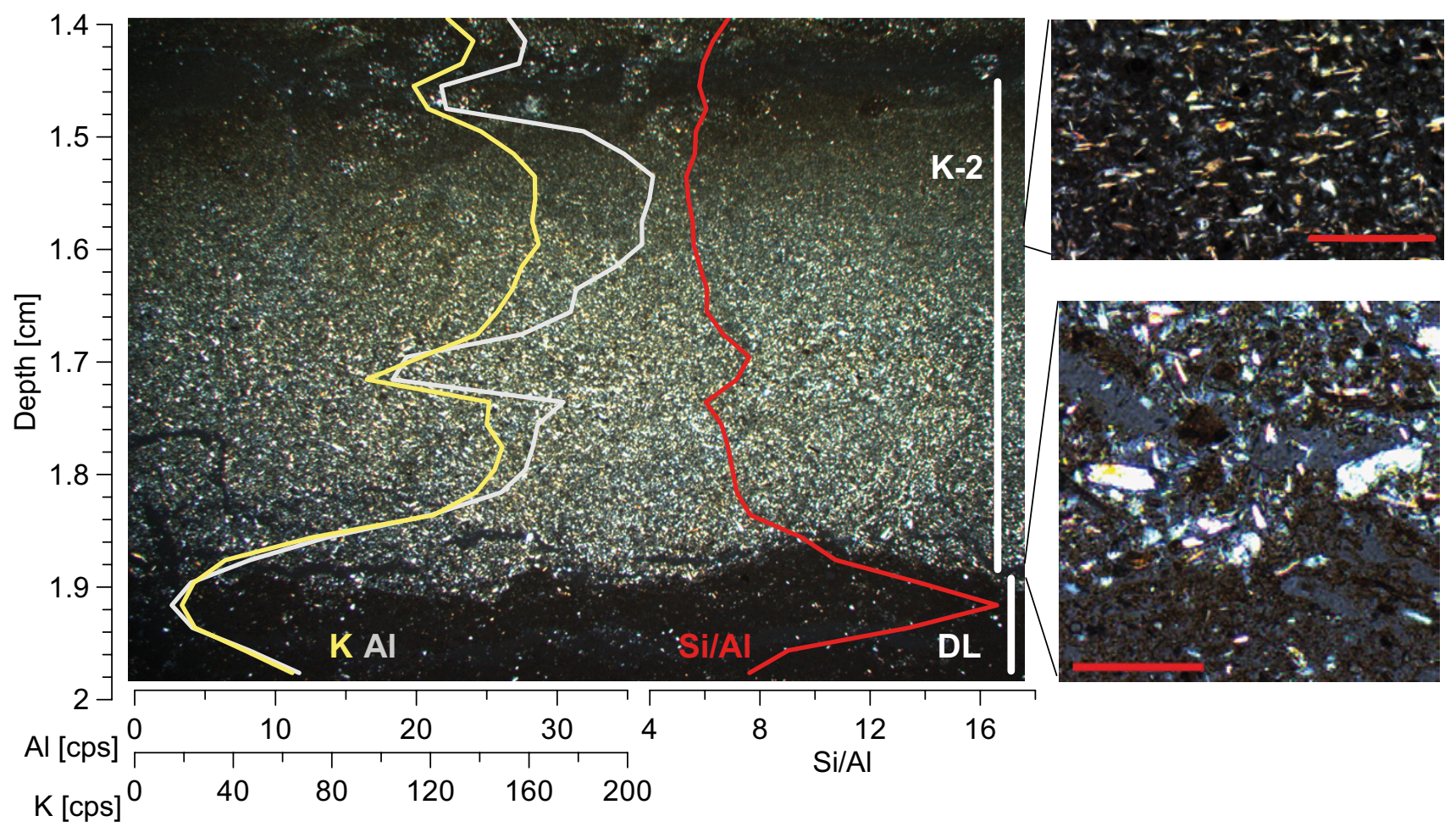

Fig. 4: Microfacies of the thick detrital layer $\mathrm{K}-2$ with $\mu$-XRF profiles of Al (grey line), $K$ (yellow line) and Si/Al ratio (red line) obtained from core TSLM 12-1 (basin center). Note the diatom layer DL underlying K-2. Thin section images were taken under crossed polarized light with $12.5 x$ magnification (big image) and 100x magnification (small images), red scale bars: $100 \mu \mathrm{m}$.

Abb. 4: Mikrofazies der detritischen Lage K-2 mit $\mu$-XRF Profilen von Al (graue Linie), K (gelbe Linie) und Si/Al (rote Linie), gemessen am Kern TSLM 12-1 (Beckenmitte). DL markiert eine Diatomeenlage, unterhalb von K-2. Dünnschliffbilder wurden unter gekreuzt polarisiertem Licht mit 12.5x Vergrößerung (großes Bild) bzw. 100x Vergrößerung (kleine Bilder) aufgenommen, rote Skalen: $100 \mu \mathrm{m}$.

trine sediments formed since infilling the reservoir in 1932 (unit II). This boundary was observed in sediment depths between $14.5 \mathrm{~cm}$ at marginal locations (TSLM 15) and $29.0 \mathrm{~cm}$ in the central basin (TSLM 12-2) and is expected even deeper in locations near the dam where it has not been found in cores reaching a sediment depth of $30.5 \mathrm{~cm}$ (TSLM 2) and $33.0 \mathrm{~cm}$ (TSLM 1), respectively. For those and seven other cores (Tab. 2) it is assumed that they did not reach the base of lacustrine sediments.

The lacustrine sediment sequence (unit II) was divided into four subunits IIa-d, based on variations in sediment color, bulk density, TOC, biogenic silica (BSi), aluminum $(\mathrm{Al})$, silicon:aluminum ratio $(\mathrm{Si} / \mathrm{Al})$ and abundance of organic matter (Fig. 3).

Sediment unit IIa is characterized by a light brownish color and consists of a predominantly minerogenic, finegrained homogenous matrix. Water contents, TOC, BSi, $\mathrm{Al}$ and $\mathrm{Si} / \mathrm{Al}$ remain almost constant within this unit. Low values of TOC (5\%) and water content (65\%) and high $\mathrm{Al}$ count rates confirm higher minerogenic contents compared to the upper subunits.

Sediment unit IIb represents a thin and dark brownish horizon, ranging in thickness from $0.5 \mathrm{~cm}$ in the basin center (TSLM 4) to $2.6 \mathrm{~cm}$ close to the dam (TSLM 2) and was observed only at coring sites exceeding $25.0 \mathrm{~m}$ water depth (TSLM 1, 2, 4, 12-1, 12-2). The horizon predominantly consists of plant remains and amorphous organics, resulting in a sharp increase in TOC values of about $2 \%$ (Fig. 3).

Sediment unit IIc is light brownish and macroscopically rather similar to sediment unit IIa. The total thickness of sediment units IIa-c ranges from $11.6 \mathrm{~cm}$ at the distal site TSLM 7 to $>27.0 \mathrm{~cm}$ next to the dam (TSLM 1), where the basis of sediment unit IIa, the onset of lacustrine sedimentation, is below the base of the core. Compared to sediment unit IIa, unit IIc is characterized by a higher content of organic matter, displayed in higher TOC between 6 and $7 \%$, lower $\mathrm{Al}$ count rates and a decreased bulk density $\left(0.3 \mathrm{~g} \mathrm{~cm}^{-3}\right)$. A slight increase in diatom abundance within sediment unit IIc was observed in thin sections. This is confirmed by slightly increasing BSi values of around $4 \%$ and $\mathrm{Si} / \mathrm{Al}$, used as a proxy for biogenic silica (FrAncus et al. 2009).

A sharp boundary between the light brownish sediment unit IIc and the uppermost darker unit IId was detected in all cores in depths between $4 \mathrm{~cm}$ at the basin center (TSLM 5) and $5.4 \mathrm{~cm}$ near the dam (TSLM 2) to $8.2 \mathrm{~cm}$ at the proximal position TSLM 7. Compared to lower sediment units, unit IId is characterized by higher organic matter contents reflected in an increase of TOC of about $1.5 \%$ and abundance of diatoms, entailing a sharp rise of BSi values of more than $10 \%$. Only in this sediment unit diatom frustules form discrete layers (Fig. 4, Fig. 5), which causes distinct peaks in the $\mathrm{Si} / \mathrm{Al}$ ratio (Fig. 3).

A characteristic feature of sediment unit IId is an intercalated light-colored detrital layer (Fig. 4), found at all locations except in two shallow water cores located in the southernmost, channel-like part of the basin close to the inflow of the Wilde Weißeritz river (TSLM 8-2: $13.3 \mathrm{~m}$ water depth, TSLM 8-3: $9.3 \mathrm{~m}$ water depth). The layer ranges in thickness from $5 \mathrm{~mm}$ in near dam locations (TSLM 13-1: 

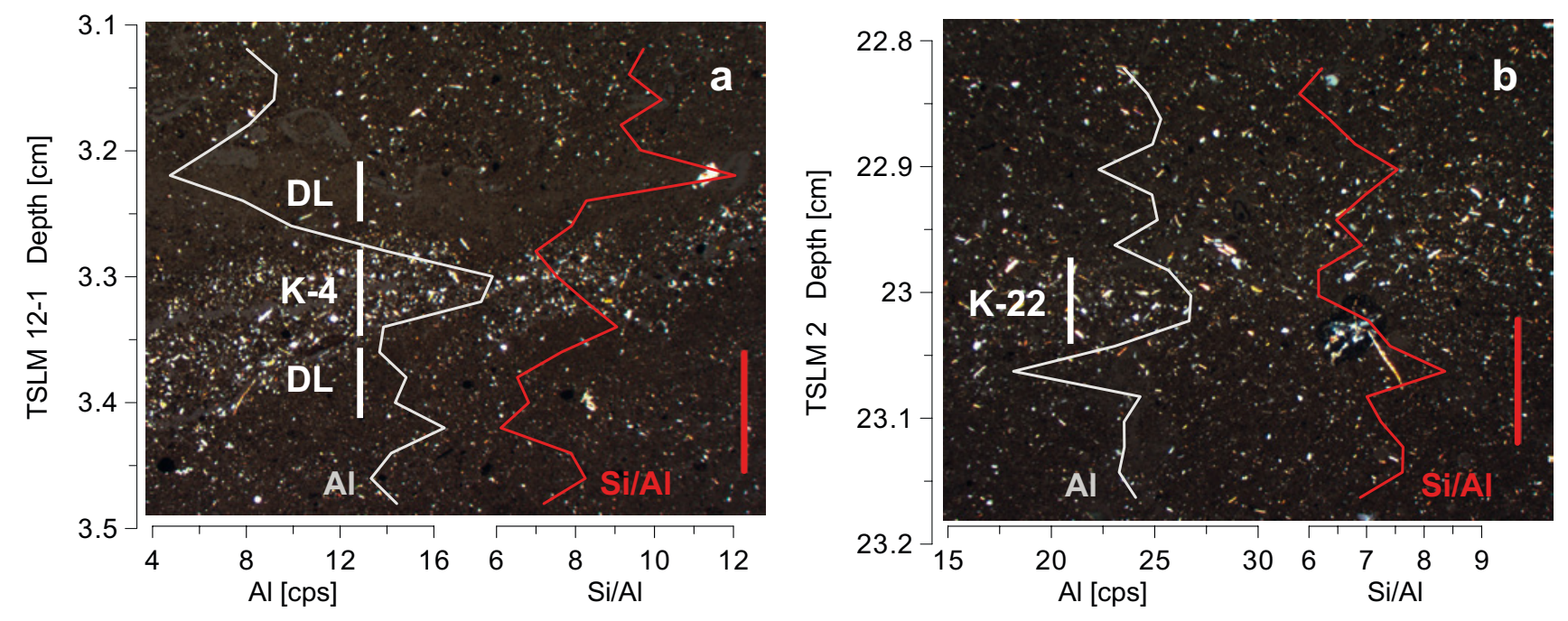

Fig. 5: Microfacies of thin detrital layers and $\mu$-XRF profiles of Al (grey line) and Si/Al ratio (red line). (a) Detrital layer K-4 in sediment unit IId with overand underlying diatom layers (DL) (TSLM 12-1). (b) Detrital layer K-22 in sediment unit IIa (TSLM 2). Thin section images were taken under crossed polarized light with $12.5 x$ magnification, scale bar: $1 \mathrm{~mm}$.

Abb. 5: Mikrofazies dünner detritischer Lagen und $\mu$-XRF Profile von Al (graue Linie) und Si/Al (rote Linie). (a) Detritische Lage K-4 in Sedimenteinheit IId mit Diatomeenlagen (DL) darüber und darunter (TSLM 12-1). (b) Detritische Lage K-22 in Sedimenteinheit IIa (TSLM 2). Dünnschliffbilder wurden unter gekreuzt polarisiertem Licht mit 12.5x Vergrößerung aufgenommen, Skala: $1 \mathrm{~mm}$.

$29.0 \mathrm{~m}$ water depth) to $33 \mathrm{~mm}$ closer to the inflow of the Wilde Weißeritz river (TSLM 7: $17.2 \mathrm{~m}$ water depth) and is mainly composed of detrital, minerogenic matter (Fig. 4). Most abundant minerals are mica, quartz, feldspar and clay minerals. The structure of this layer is characterized by normal grading, shown in decreasing grain sizes upwards within the layer, as measured in thin sections. Grain diameters in the basal part range from 40 to $60 \mu \mathrm{m}$ and only occasionally individual grains exceed $100 \mu \mathrm{m}$ in diameter. Quartz and feldspar minerals are dominating the coarse grained fraction, whereas in the upper part of the layer, more fine grained horizontally arranged mica minerals are abundant (Fig. 4). The mineralogical sorting upwards within the layer is illustrated by increasing $\mathrm{Al}$ and potassium (K) counts, reflecting an upward increase of clay mineral and mica contents. In general, the thickness of the top clay layer is increasing towards the dam at the expense of the silt-sized part and is absent in the most proximal sediment cores TSLM 6, 7 and 8-1.

The total sediment input through this discrete detritalminerogenic layer into the reservoir has been calculated to approx. 2,400 $\mathrm{t}$ by multiplying the measured density of the layer with the estimated volume. A total volume of $4,800 \mathrm{~m}^{3}$ was calculated by linear interpolation of layer thickness between sample points and rough extrapolation of the layer up to the rising lateral slopes (Fig. 8). More than $65 \%$ of the sediment load was deposited between the core locations TSLM 6 and TSLM 8-1 encompassing the southern-central part of the basin, where accumulation rates reach $14.0 \mathrm{~kg}$ $\mathrm{m}-2$ in contrast to $3.4 \mathrm{~kg} \mathrm{~m}-2$ close to the dam.

In addition to this exceptional layer, microfacies analyses enabled to identify 22 further detrital layers (Fig. 5), of which 16 are intercalated in sediment units IIc and IId (Fig. 7). Within sediment unit IIa seven layers appear in two cores close to the dam in water depth $>30.0 \mathrm{~m}$ (TSLM $1,2)$ and three in the basin center (TSLM 4: $26.0 \mathrm{~m}$ water depth). All these additional detrital layers range in thick- ness from $0.5 \mathrm{~mm}$ to $3.5 \mathrm{~mm}$ (Fig. 7) and are mainly composed of minerogenic medium to fine silt grains. In some cases, plant remains are also included. Internal structures like grading have not been observed. Due to their detritalminerogenic composition, even thin detrital layers can be distinguished from matrix sediments in the Al scan (Fig. 5, Fig. 7).

The abundance of detrital layers in different cores varies depending on their location within the basin (Tab. 3). The largest number of detrital layers has been observed in cores $>25.0 \mathrm{~m}$ water depth (TSLM 1, 2, 4, 12-1, 12-2, 13-1, 14-1), proving a bottom wide distribution of these layers in the deepest part of the reservoir. In shallow water locations (TSLM 7, 8-1, 9-2) thin detrital layers are absent, likely due to erosion during low water levels (HÅKANSON 1982).

\subsection{Chronology}

${ }^{137} \mathrm{Cs}$ chronologies were established for three cores: TSLM 2 (water depth: $30.5 \mathrm{~m}$ ) close to the main dam, TSLM 12-2 (water depth: $29.0 \mathrm{~m}$ ) in the basin center and TSLM 7 (water depth: $17.2 \mathrm{~m}$ ) in the southern part close to the river inflow (Fig. 6). The profiles from the two deep cores clearly exhibit two peaks in ${ }^{137} \mathrm{Cs}$ activity, related to nuclear weapon tests in 1963 and to the Chernobyl fallout in 1986 (Putyrskaya et al. 2009). These ${ }^{137} \mathrm{Cs}$ peaks do not appear distinctly in core TSLM 7, likely due to the shallow-water location (water depth: $17.2 \mathrm{~m}$ ). Similar observations were made in sediment cores from shallow water locations in Lago Maggiore by PUTYrskayA et al. (2009). It is assumed that the signal faded out due to sediment mixing during times of lower water levels. Water depth at this location was at maximum 4.0 m between 1989 and 1992 and in 2001 and 2003. In the years 1975, 1976 and 1980 this location dried up completely. The topmost sediments at this site (core TSLM 7) consist of intermixed clastic material typically indicating sediment reworking (unit X in Fig. 6). 
Tab. 3: List of runoff events of the Wilde Weißeritz river $\left(Q_{d}>8 \mathrm{~m}^{3} \mathrm{~s}^{-1}\right)$ from 1932 to 2007 and coincided detrital layers (K-1 to K-23) correlated between different coring sites (TSLM 1 to TSLM 15). Thickness of K-2 (in $\mathrm{mm}$ ) was measured in thin sections.

Tab. 3: Abflussereignissen der Wilden Weißeritz $Q_{d}>8 \mathrm{~m}^{3} \mathrm{~s}^{-1}$ (1932-2007) und Zuordnung zu detritische Lagen (K-1 bis K-23) in verschiedenen Kernsequenzen (TSLM 1 bis TSLM 15). Die Dicke der Lage K-2 (in $\mathrm{mm}$ ) wurde in Dünnschliffen gemessen.

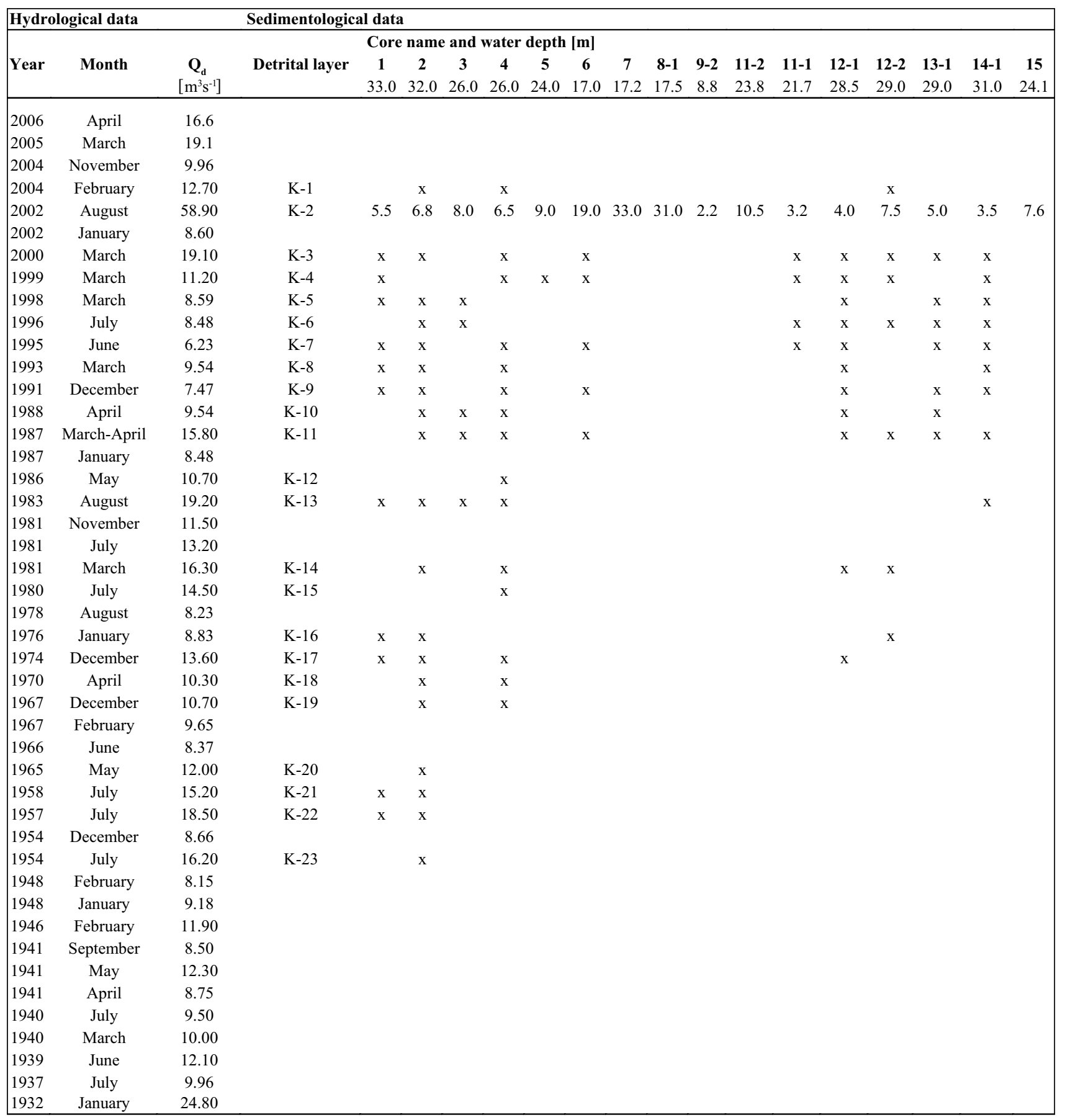

The 1963 and $1986{ }^{137} \mathrm{Cs}$ peaks in cores TSLM 2 and TSLM 12-2 form two anchor points for the chronology. In addition, the base of the lacustrine sedimentation (transition between sediment units I and IIa) in core TSLM 12-2 marks the initial infilling of the reservoir in 1932. The conspicuous thick detrital layer K-2 intercalated in sediment unit IId (Fig. 6) is interpreted as deposit of the exceptional flood event in August 2002. The age-depth model was performed by linear interpolation between these anchor points.

Core-to-core correlation based on three further lithological markers allowed transferring this chronology to the other investigated cores (Fig. 6). Two of these markers ap- pear in each core: (1) the detrital layer K-2 deposited in 2002 and (2) the boundary between the two sediment units IIc and IId dated to 1995. Besides the aforementioned transition between sediment units I and II (1932), a fourth macroscopically discernible marker, found in locations $>25.0 \mathrm{~m}$ water depth (TSLM 1, 2, 4, 12-1, 12-2), is the base of the dark colored sediment unit IIb. Linear interpolation dates this shift to 1975, at the time when the reservoir was almost completely emptied. This is in agreement with the interpretation of this layer as resuspended littoral material. The core chronologies are further confirmed by correlation of other thin detrital layers (Fig. 6, Fig. 7). 

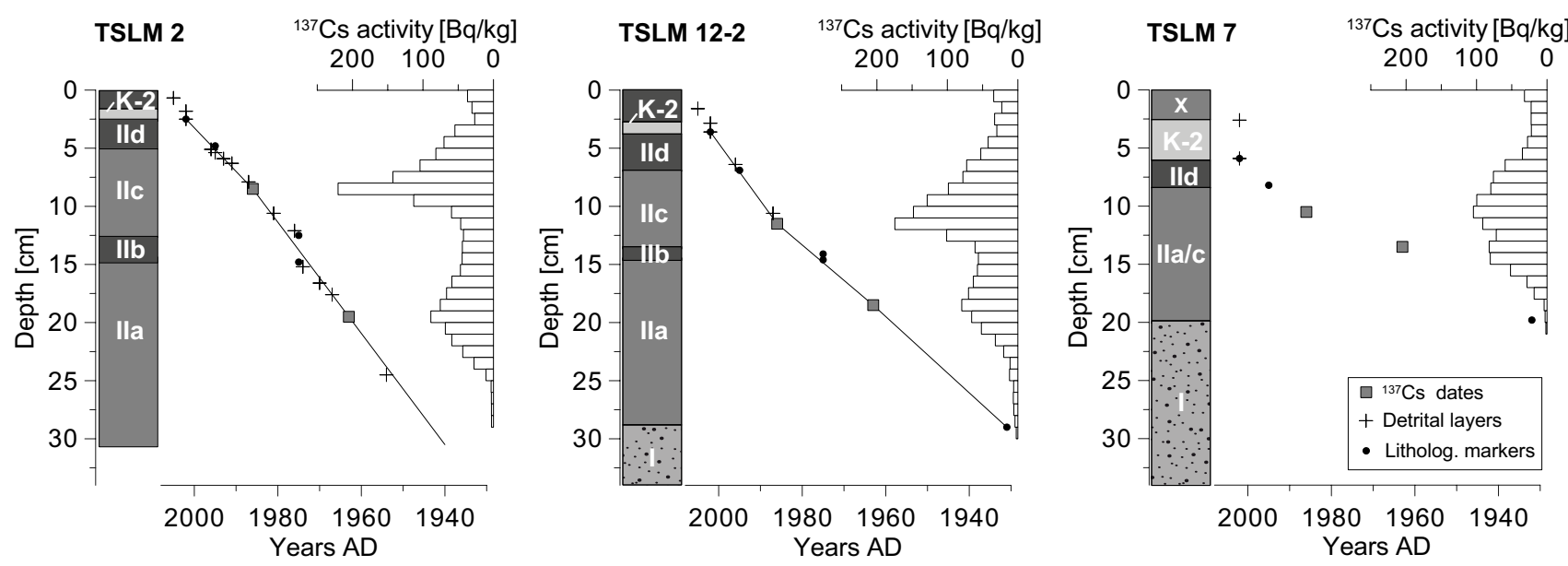

Fig. 6: Chronology of sediment sequences TSLM 2, TSLM 12-2 and TSLM 7 based on linear interpolation between the ${ }^{137}$ Cs peaks in 1963 and 1986 (squares). Core-to-core correlation was done applying distinct lithological markers (dots): the detrital layer K-2 within sediment unit IId, the border between sediment units IIc and IId, sediment unit IIb and the border between sediment units I/IIa marking the onset of lacustrine sedimentation in 1932. Crosses mark the positions of further thin detrital layers coincided to instrumentally documented floods.

Abb. 6: Chronologie der Sedimentsequenzen TSLM 2, TSLM 12-2 und TSLM 7 basierend auf linearer Interpolation zwischen ${ }^{137}$ Cs Maxima 1963 und 1986 (Quadrate). Korrelation der Kerne anhand lithologischer Markerhorizonte (Punkte): detritische Lage K-2 in Sedimenteinheit IId, Grenze zwischen Sedimenteinheiten IIc und IId, Sedimenteinheit IIb und Grenze zwischen Sedimenteinheiten I und IIa, welche den Beginn der lakustrinen Sedimentation markiert (Talsperre in Betrieb seit 1932). Die Kreuze markieren weitere dünne detritische Lagen, die mit Hochwasserereignissen korreliert wurden.

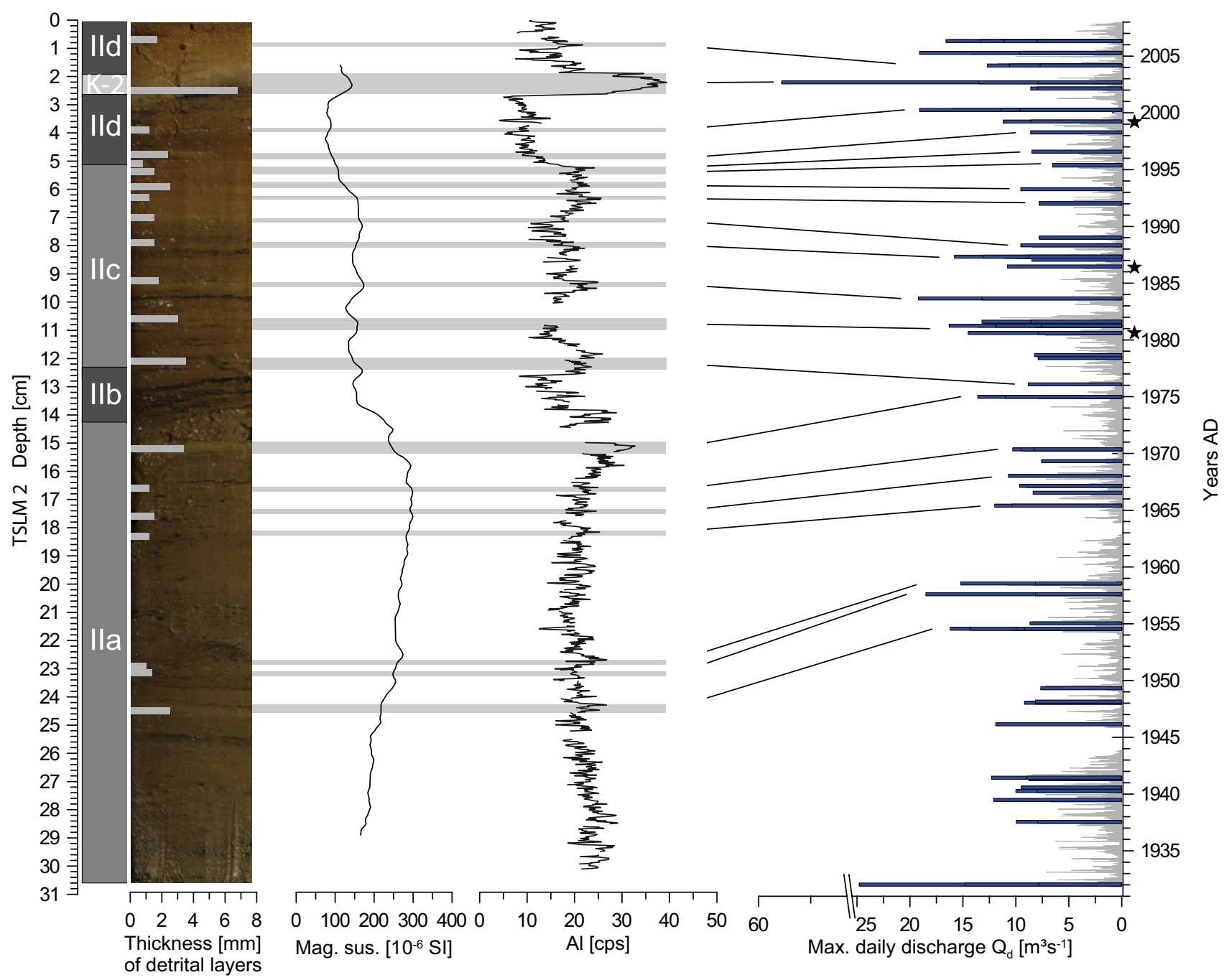

Fig. 7: Chronology of detrital layers in core TSLM 2: left hand: core photo and thickness of detrital layers, magnetic susceptibility and $\mu$-XRF counts of Al. Right hand: daily discharge values $\left(Q_{d}\right)$ of Wilde Weißeritz (blue bars: $Q_{d}>8 \mathrm{~m}^{3} \mathrm{~s}^{-1}$ ) and correlation to detrital layers (black lines). Stars mark three floods which do not correlate to detrital layers in TSLM 2 but to layers in other cores (Tab. 3).

Abb. 7: Chronologie detritischer Lagen in Kern TSLM 2: links: Kernfoto mit Lagenmächtigkeit und Profile der magnetischen Suszeptbilität (Mag. sus.) und Al ( $\mu$-XRF). Rechts: mittlere Tagesabflüsse $\left(Q_{d}\right)$ der Wilden Weißeritz (blaue Balken: $\left.Q_{d}>8 \mathrm{~m}^{3} \mathrm{~s}^{-1}\right)$ und Zuordnung zu detritischen Lagen (schwarze Linien). Drei Hochwasserereignisse (schwarze Sterne) korrelieren nicht mit detritischen Lagen im Kern TSLM 2 aber mit Lagen in anderen Kernen (Tab. 3). 


\subsection{Detrital layers versus hydrological data}

Flood events during the period 1932-2007 were identified by maximum values of daily discharges $\left(Q_{d}\right)$ of the main tributary Wilde Weißeritz. In order to relate the identified 23 detrital layers to instrumentally observed flood events the strongest 24 floods with $Q_{d}>10 \mathrm{~m}^{3} \mathrm{~s}^{-1}$ are chosen for comparison. According to the established age model 16 detrital layers coincide with runoff events $>10 \mathrm{~m}^{3} \mathrm{~s}^{-1}$ (Tab. 3). Five of the seven other detrital layers occurring in sediment units IIb-d coincide to floods with $Q_{d}=8-10 \mathrm{~m}^{3} \mathrm{~s}^{-1}$, while only two detrital layers appear to be in accord with floods with $Q_{d}<8 \mathrm{~m}^{3} \mathrm{~s}^{-1}$. This suggests that a daily runoff of ca $8-10 \mathrm{~m}^{3} \mathrm{~s}^{-1}$ represents a threshold for the deposition of a detrital layer at the reservoir floor (Tab. 3, Fig. 7).

In general, clastic-detrital layers are best recognizable in the more organic sediment units IIb-d (1975-2007) because of the higher contrast of these darker matrix sediments to the very fine minerogenic layers. From the eight floods, not detected there, five occur in years with more than one flood event $(2004,2000,1987,1981)$. One further event, not found in the sediment record, is rather weak close to the lower threshold $\left(Q_{d}=8.2 \mathrm{~m}^{3} \mathrm{~s}^{-1}\right.$ in September 1978) and thus likely did not lead to detrital layer deposition in the main basin. The two remaining non-detected flood layers in 2005 and 2006 might be diminished with matrix sediments in the uppermost unconsolidated centimeters of the sediment cores and thus are not detectable as distinct layers. In the lower, more minerogenic sediment unit IIa (1932-1975) only seven detrital layers have been detected likely triggered by floods $>10 \mathrm{~m}^{3} \mathrm{~s}^{-1}$ (Tab. 3, Fig. 7).

Outstanding in the runoff record since 1932 is the flood event taking place in August 2002. Torrential rainfall events in Central Europe were caused by the persistence of a specific weather regime, called "Trough over Central Europe", which caused transport of very moist air from the Mediterranean Sea to eastern Central Europe. Enhanced by orographic effects, extreme precipitation amounts fell in eastern Erzgebirge between 11th and 13th of August. The maximum of $321 \mathrm{~mm}$ in $24 \mathrm{~h}$ was reported from weather station Zinnwald-Georgenfeld, approx. $15 \mathrm{~km}$ southeast of the Lehnmühle Reservoir (LfULG 2004, Fig. 1). The daily discharge on August 12th was calculated to $59 \mathrm{~m} 3 \mathrm{~s}-1$ and the modeled peak discharge reached $133 \mathrm{~m}^{3} \mathrm{~s}^{-1}$ (LfULG 2004). The second strongest daily discharge since building of the Lehnmühle dam amounts to some $24 \mathrm{~m}^{3} \mathrm{~s}^{-1}$ and was measured in January 1932, emphasizing the exceptional intensity of the 2002 flood event. The thickness of the resulting detrital layer ranges from $5 \mathrm{~mm}$ in distal locations to $33 \mathrm{~mm}$ in proximal areas and, thus, by far exceeds the thickness of all other detrital layers in the record, reaching $3.5 \mathrm{~mm}$ in maximum (Fig. 7).

\section{Discussion}

\section{1 Processes of detrital layer deposition}

Detrital layers in lake sediments commonly are interpreted as natural flood records deposited by turbidity currents of the inflowing stream (e.g. CZymzik et al. 2010, GiLBerT et al. 2006, Gilli et al. 2003, LAmoureux 2000, LudLAM
1974, Mangili et al. 2005, Sturm $\mho$ Matter 1978). Here we present, for the first time, a multiple core record of flood layers deposited during the last three decades in a reservoir. Except one all detrital layers were less than $5 \mathrm{~mm}$ thick and thus could only be detected by microscopic techniques indicating low sediment input during these events and therefore low density over- or interflows (MULDER \& AlexANDER 2001, Sturm $\mho$ MATter 1978) are the ordinary sediment transport mechanisms within the reservoir basin following floods due to sediment loss by braking of the sediment laden stream in the upstream pre-basin (Fig. 1c).

Overall 16 detrital layers were correlated with runoff events back to 1976, resulting in a 'recording rate' (deposition of a detrital layer) of $64 \%$. Most of the non-detected layers appear in years with more than one flood event (Tab. 3). The fine grained particles likely accumulated from the different floods without discernible borders in between (Siegenthaler \& Sturm 1991). An increase in layer thickness towards the dam was observed in nine cases likely caused by focusing of suspended sediments (HÅKANSON 1982). Compared to natural lakes sediment focusing in reservoirs is directed towards the dam rather than the centre of the lake. This is due to water level drawdown and water outlet at the dam wall, generating a steady motion of water and suspended sediment towards the dam (SнотвоLт et al. 2005). Consequently, the record of flood layers is most complete in the near dam area (TSLM 2).

The occurrence of detrital layers related to two thirds of all discharge events proves that the pre-basin does not fully impede detrital matter flux into the main basin. The effect of the pre-dam, however, also depends on the water level. During water levels below the base level of the predam (approx. $515 \mathrm{~m}$ a.s.l.), the basin in front loses its function and the inflowing stream directly enters the reservoir, resulting in thicker deposits. Thus layer thickness depends on core location and water level during the flood event (SNYDER et al. 2006) and is not directly related to flood intensity as observed in some lakes (e.g. ScHIEFER et al. 2011).

An exceptionally thick detrital layer was formed in 2002 after the major hydrometeorological event that was responsible also for the catastrophic flood of the Elbe River (BfG 2002, LfULG 2004). In contrast to our expectation, no coarse sand and gravel has been found even in most proximal locations. The absence of coarser material can be explained with the existence of the pre-dam, which reduced the discharge velocity leading to the deposition of coarser sediments in the small basin in front of the dam. This proves that the dam effectively traps sediments before entering the reservoir. Although the magnitude of this flood resulted in an unprecedented short-term sediment input into the reservoir, a much higher sediment flux must be assumed without the dam.

Sediment transport into the reservoir likely took place by high turbidity currents (MULDER \& ALEXANDER 2001, STURM \& MATTER 1978) as inferred from the graded structure of the detrital layer and a decreasing layer thickness in distal direction. Traces of small-scale erosion by the sediment laden current appear in the proximal core TSLM 8-1, where the layer reaches $31 \mathrm{~mm}$ in thickness. An approx. $1 \mathrm{~mm}$ thick diatom layer directly beneath the flood layer, observed in all other more distal cores (Fig. 4), is missing 
at this location. This indicates that density of the sediment laden stream exceeded surrounding water density, resulting in a high density turbidity current, which moved along the basin floor after entering the reservoir (FINGER et al. 2006, Mulder $\mho$ Alexander 2001, Sturm $\mho$ Matter 1978). The absence of the detrital layer in the narrow bay on the southern margin of the reservoir (TSLM 8-2, TSLM 8-3) probably is due to the high flow velocity of the sediment laden current in this channel-like part of the basin preventing from sediment deposition (DE CESARE et al. 2001). Moreover, eventually deposited detrital material could have been eroded from this location in summer 2003 when the lake level was so low, that this part of the basin became exposed and thus vulnerable to erosion.

\subsection{Intra-basin distribution of the 2002 flood layer}

The thickness distribution of the 2002 flood layer (Fig. 8) reveals maximum sediment deposition between the proximal core locations TSLM 8-1 and TSLM 6, representing the southern part of the N-S directed central part of the basin directly north of the junction with the NW-SE directed narrow channel which forms an elongation of the inflowing stream. Layer thickness in the area of maximum deposition ranges from 19 to $33 \mathrm{~mm}$. Around $65 \%$ of the sediment load is accumulated in this area, which accounts for approx. one third of the reservoir floor. The high deposition in this area is caused by the particular basin morphometry. The widening of the basin at this point causes a slow-down of the sediment laden water plume, which in turn leads to immediate sediment deposition. The slow-down effect was further enhanced by the kink of the basin at the junction of the main basin and the channel-like part in the south. To the north of the area of maximum sediment accumulation, the sediments are distributed almost evenly over the reservoir floor, contrasting an expected thinning of flood layers in distal direction as observed in many natural lakes (e.g. Drohmann \& NegEndank 1993, MANGiLi et al. 2005, StURM \& MATTER 1978). Detailed microscopic analysis, however, has proven that the thickness of the coarser grained basal section indeed decreased in distal direction, but this decrease was compensated by an increasing thickness of the fine-grained clay top. A high clay accumulation rate in the distal near-dam area is favored by a water current through the basin towards the dam due to water release through outlets in the middle and upper parts of the dam wall in order to discharge the reservoir during the flood event (PAUl \& SCHEIFHACKEN 2010). A secondary maximum in sediment deposition has been found in front of a small bay in the northwestern part of the basin (Fig. 8). Despite plantation of trees around the reservoir to prevent from erosion, sediments have been transported into the basin through a non-permanently water bearing stream channel. Comparable sediment fluxes can be expected also through three further channels on the eastern shoreline, but since no cores have been obtained from this area this remains speculative.

The grid of available sediment cores allows an approximation of total sediment influx during the 2002 summer flood, calculated to 2,400 tons. This value is a minimum estimate, because of the aforementioned expected higher

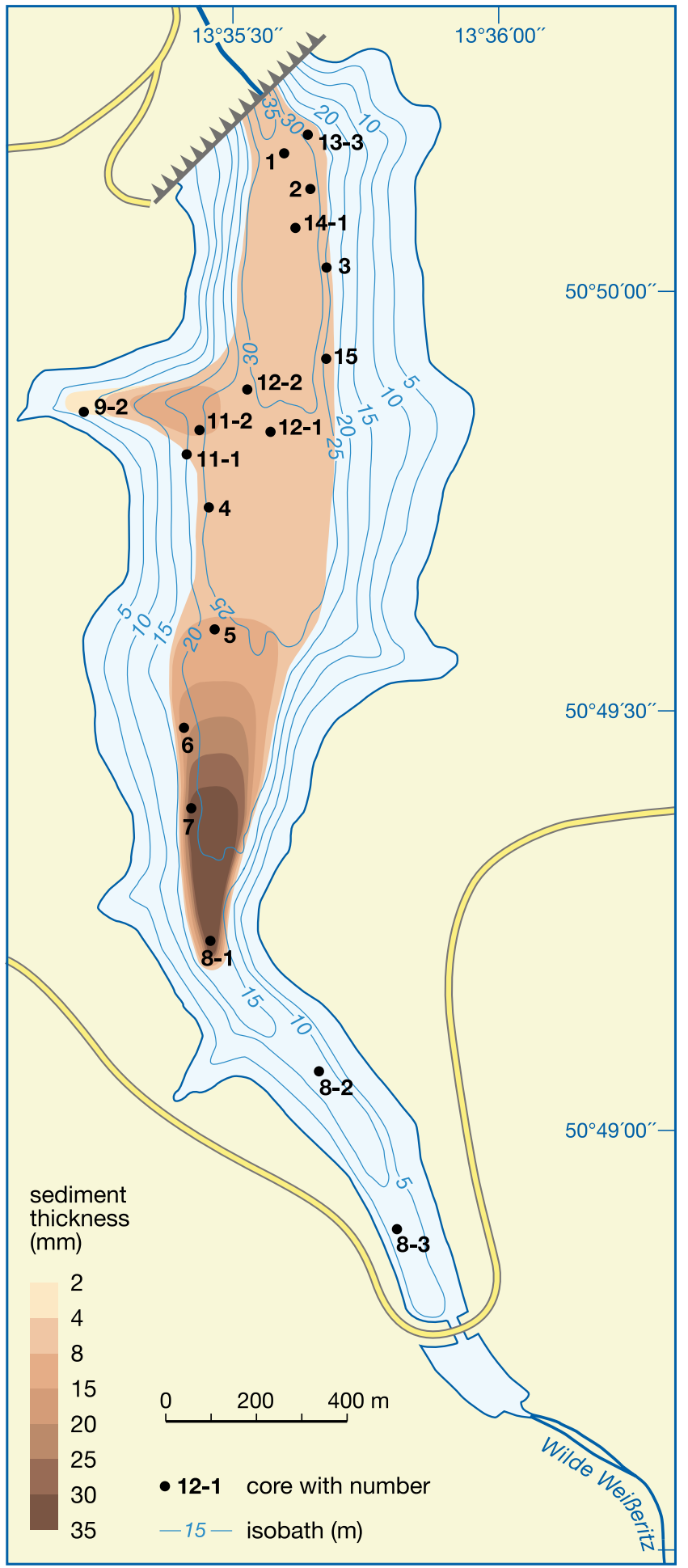

Fig. 8: Spatial distribution map of the 2002 detrital layer $(K-2)$ as measured in thin sections. Black dots mark the different coring sites.

Abb. 8: Verteilungskarte der detritischen Lage des fahres 2002 aus Messungen der Lagenmächtigkeit in Dünnschliffen. Kernpositionen im Talsperrenbecken sind mit schwarzen Punkten markiert.

deposition rates in front of small channels on the eastern shoreline which have not been taken into account. Moreover, our mass estimation is only based on the in-situ deposits and does not consider any kind of reworking which has been observed only in one core (TSLM 7) where a $26 \mathrm{~mm}$ thick layer of reworked detrital material overlays 
the K-2 flood layer. Also not included in our calculation is the amount of sediment trapped in the pre-basin. Information about the trap efficiency during the exceptional high magnitude floods is not available so far.

The accumulated mass of the 2002 flood layer was furthermore compared with the total accumulated sediment in the two master cores (TSLM 2, TSLM 12-2), where dry weight was measured on volumetric samples from the detrital layer and the complete core sequence. Sediment delivery in 2002 reached around $0.28 \mathrm{~g} \mathrm{~cm}^{-2}$ close to the dam (TSLM 2) and $0.38 \mathrm{~g} \mathrm{~cm}^{-2}$ in the middle of the basin (TSLM $12-2$ ), where it accounts for $6.2 \%$ of the cumulated sediment yield since $1932\left(6.0 \mathrm{~g} \mathrm{~cm}^{-2}\right)$. The accumulation exceeds the annual mean by 4.5 times at the basin center (TSLM 12-2: $0.09 \mathrm{~g} \mathrm{~cm}^{-2} \mathrm{a}^{-1}$ ) and by 2.2 times in the near dam area (TSLM 2: $\left.0.13 \mathrm{~g} \mathrm{~cm}^{-2} \mathrm{a}^{-1}\right)$. The lower imprint of the flood event at the distal site (TSLM 2) primarily relates to the higher sediment ratio since 1932 caused by sediment focusing to the deepest parts close to the dam. Sediment focusing is favored by water level drawdown and the steady water flow driven by the continuous water withdrawal for drinking water supply (SнотвоLт et al. 2005).

\section{Conclusions}

Investigating multiple sediment cores enabled detailed insights into processes of sediment deposition in the Lehnmühle reservoir caused by the severe 2002 summer flood. The sediment flux into the reservoir resulted in a 5 to $33 \mathrm{~mm}$ thick layer of detrital catchment material in the entire basin, equivalent to approximately 2,400 tons. In the basin center the flood deposits accounts for approximately $6 \%$ of the total sediment yield since the construction of the reservoir in 1932. Without the upstream construction of an open dam, which effectively trapped coarser material, the sediment input most likely would have been much higher Besides the tributary Wilde Weißeritz as the primary sediment source, secondary sediment transport pathways have been identified through a non-permanently water bearing stream channel, entering the reservoir from the western shore. The distribution of sediments in the reservoir is controlled by the shape and morphometry of the basin as well as water management controlling the water flow through the reservoir and the water level.

Although depositional processes and sediment delivery related to the 2002 summer flood were exceptional for the entire history of the reservoir since the operation start date in 1932, microfacies analyses in combination with $\mu$-XRF element scanning enabled to identify another 22 discrete, but thin detrital layers. Detailed comparison with instrumental data revealed that all these layers were triggered by minor runoff events during the last decades.

In many aspects the sedimentation regime in the Lehnmühle reservoir resembles natural lake systems, however, modified by (1) the artificial sediment trap upstream in the main tributary, (2) the particular basin morphometry with the deepest part not located in the center but on the margin near the dam, and, (3) water management determining the water flow through the basin and strong water level fluctuations.

\section{Acknowledgements}

We are thankful to R. Sudbrack, T. Ihle, I. Werner and B. Böhme from the State Reservoir Administration of Saxony (LTV) for supporting sediment coring and providing useful information about Lehnmühle reservoir. For reviewing early drafts of the manuscript and stimulating discussions we thank N. Scheifhacken and C. Lorz. The State Reservoir Administration of Saxony (LTV) and the Saxony State Office for the Environment, Agriculture and Geology (LfULG) are acknowledged for providing runoff data of the Wilde Weißeritz. We would like to thank D. Berger and G. Arnold for preparing high-quality thin sections, N. Nowaczyk for magnetic susceptibility measurements, B. Plessen and P. Meier for TOC measurements, K. Speth for performing the gamma-spectometric measurements and C. Kaulfuss, S. Pinkerneil, M. Kuntzsch and T. Junker for their support during sediment coring and subsampling. A. Hendrich helped with the layout of the figures. This is a contribution to the PROGRESS joint project funded by the German Federal Ministry of Education and Research (BMBF).

\section{References}

BAKer, V. R. (2006): Palaeoflood hydrology in a global context. - Catena, 66: 161-168. DOI:10.1016/j.catena.2005.11.016.

Bernhofer, C., Goldberg, V., Franke, J., Häntzschel, J., Harmansa, S., Pluntke, T., Geidel, K., Surke, M., Prasse, H., Freydank, E., Hänsel, S., Mellentin, U. \& Küchler, W. (eds., 2008): Sachsen im Klimawandel - Eine Analyse. - 211 S.; Dresden.

Best, J. L., Kostaschuk, R. A., Peakall, J., Villard, P. V. \& Franklin, M (2005): Whole flow field dynamics and velocity pulsing within natural sediment-laden underflows. - Geology, 33(10): 765-768. DOI: 10.1130/ G21516.1.

BFG (Federal Institute of Hydrology) (2002): Das Augusthochwasser 2002 im Elbegebiet. - 49 S.; Koblenz.

Brauer, A. (2004): Annually laminated lake sediments and their palaeoclimatic relevance. - In: Fischer, H., Kumke, T., Lohmann, G., Flöser, G., Miller, H., von Storch, H. \& Negendank, J. F. W. (eds.), The Climate in Historical Times: Towards a Synthesis of Holocene Proxy Data and Climate Models: 109-128; Berlin, Heidelberg (Springer).

Brauer, A. \& CASANOva, J. (2001): Chronology and depositional processes of the laminated sediment record from Lac d'Annecy, French Alps. Journal of Paleolimnology, 25: 163-177. DOI: 10.1023/A:1008136029735.

Brauer, A., Dulski, P., Mangili, C., Mingram, J. \& Liu, J. (2009): The potential of varves in high-resolution paleolimnological studies. - Pages News, 17: 96-98.

Chapron, E., Arnaud, F., Noel, H., Revel, M., Desmet, M. \& Perdereau, L. (2005): Rhone River flood deposits in Lake Le Bourget: a proxy for Holocene environmental changes in the NW Alps, France. - Boreas, 34: 404-416. DOI: 10.1080/03009480500231260.

Czymzik, M., Dulski, P., Plessen, B., von Grafenstein, U., Naumann, R. \& BRAuER, A. (2010): A 450-year record of spring/summer flood layers in annually laminated sediments from Lake Ammersee (Southern Germany). - Water Resources Research, 46: W11528. DOI: 10.1029/2009WR008360.

De Cesare, G., Schleiss, A. ¿ Hermann, F. (2001): Impact of turbidity currents on reservoir sedimentation. - Journal of Hydraulic Engineering, 127: 6-16.

Francus, P., Lamb, H., Marshall, M. \& Brown, E. (2009): The potential of high-resolution X-ray fluorescence core scanning: Applications in paleolimnology. - Pages News, 17: 93-95.

Drohmann, D. \& Negendank, J. F. W. (1993): Turbidites in the sediments of Lake Meerfelder Maar (Germany) and the explanation of suspension sediments. - In: Negendank, J. F. W. \& ZolitschKA, B. (eds.) Paleolimnology of European Maar Lakes: 195-208; Berlin, Heidelberg (Springer).

Engstrom, D. R. \& Wright, H. E. (1984): Chemical stratigraphy of lake sediments as a record of environmental change. - In: HAYWORTH, 
E. Y. \& LunD, J. W. G. (eds): Lake Sediments and Environmental History: Studies in Palaeolimnology and Palaeoecology: 11-67; Leicester (Leicester University Press).

Effler, S. W., Matthews, D. A., Kaser, J. W., Prestigiacomo, A. R. \& SMith, D. G. (2006): Runoff impacts on a water supply reservoir: suspended sediment loading, turbid plume behavior, and sediment deposition. - Journal of the American Water Resources Association, 42: 1697-1710. DOI: 10.1111/j.1752-1688.2006.tb06030.x.

Finger, D, Schmid, M. \& Wüest, A. (2006): Effects of upstream hydropower operation on riverine particle transport and turbidity in downstream lakes. - Water Resources Research, 42: W08429. DOI: 10.1029/2005WR004751.

Gilbert, R., Crookshanks, S., Hodder, K. R., Spagnol, J. \& Stull, R. B. (2006): The record of an extreme flood in the sediments of montane Lillooet Lake, British Columbia: Implications for paleoenvironmental assessment. - Journal of Paleolimnology, 35: 737-745. DOI: 10.1007/ s10933-005-5152-8.

Gilli, A., Anselmetti, F. S., Ariztegui, D. \& McKenzie, J. A. (2003): A 600 -year sedimentary record of flood events from two sub-alpine lakes (Schwendiseen, Northeastern Switzerland). - Eclogae Geologicae Helvetiae, 96: 49-58.

HÅKANSON, L. (1982): Bottom dynamics in lakes. - Hydrobiologia, 91-92: 9-22.

HÅKAnson, L. \& Jansson, M. (eds., 1983): Principles of Lake Sedimentology. - 316 S.; Berlin, Heidelberg (Springer).

JACOB, F., FEgER, K.H. Rösch, M. ひ KLINGER, T. (2009): Akkumulation von amorphem Silizium in holozänen Seesedimenten des Herrenwieser Sees (Nordschwarzwald). - In: Böden - eine endliche Ressource Jahrestagung der DBG, September 2009. - 4 S.; Bonn.

KAulfuss, W. (1979): Sedimentbelastung und Sedimentverteilung in der Talsperre Lehnmühle. - Wissenschaftliche Zeitschrift der Pädagogischen Hochschule K.F.W. Wander Dresden, 3: 71-79.

Lamb, M. P., McElroy, B., Kopriva, B., Shaw J. \& Mohrig, D. (2010): Linking river-flood dynamics to hyperpycnal-plume deposits: Experiments, theory, and geological implications. - Geological Society of America Bulletin, 122 (9-10): 1389-1400. DOI: 10.1130/B30125.1.

LAmoureux, S. (2000): Five centuries of interannual sediment yield and rainfall-induced erosion in the Canadian High Arctic recorded in lacustrine varves. - Water Resources Research, 36: 309-318.

LfULG (Saxony State Office for the Environment, Agriculture and Geology) (eds., 2004): Ereignisanalyse - Hochwasser August 2002 in den Osterzgebirgszuflüssen. - 188 S.; Dresden.

LTV (The State Reservoir Administration of Saxony) (2002): Nitratbericht sächsischer Trinkwassertalsperren. - 52 S.; Dresden (Dr. Uwe Miersch Verlag)

LTV (The State Reservoir Administration of Saxony) (2009): Die Talsperre Lehnmühle. - 2 S.; Pirna.

Ludlam, S. D. (1974): Fayetteville Green Lake, New York. 6. The role of turbidity currents in lake sedimentation. - Limnology and Oceanography, 19: 656-664.

Mangili, C., Brauer, A., Moscariello, A. \& Naumann, R. (2005): Microfacies of detrital event layers deposited in quaternary varved lake sediments of the Pianico-Sellere Basin (northern Italy). - Sedimentology, 52: 927-943. DOI: 10.1111/j.1365-3091.2005.00717.x.
Mulder, T. \& Alexander, J. (2001): The physical character of subaqueous sedimentary density flows and their deposits. - Sedimentology, 48: 269-299. DOI: 10.1046/j.1365-3091.2001.00360.x.

Paul, L. \& Scheifhacken, N. (2010): Einfluss der Wassermengenbewirtschaftung auf die vertikale Verteilung allochthoner Trübstoffe in Trinkwassertalsperren nach Hochwässern. - In: Deutsche Gesellschaft für Limnologie (DGL) - Erweiterte Zusammenfassung der Jahrestagung 2008 (Konstanz), Oldenburg: 144-149.

Putyrskaya, V., Klemt, E. \& Röllin, S. (2009): Migration of ${ }^{137} \mathrm{Cs}$ in tributaries, lake water and sediment of Lago Maggiore - analysis and comparison to Lago di Lugano and other lakes. - Journal of Environmental Radioactivity, 100: 35-48. DOI: 10.1016/j.jenvrad.2008.10.005.

Schiefer, E., Gilbert, R. \& Hassan, M. A. (2011): A lake sediment-based proxy of floods in the Rocky Mountain Front Ranges, Canada. - Journal of Paleolimnology, 45: 137-149. DOI: 10.1007/s10933-010-9485-6.

Shotbolt, L. A., Thomas, A. D. \& Hutchinson, S. M. (2005): The use of reservoir sediments as environmental archives of catchment inputs and atmospheric pollution. - Progress in Physical Geography, 29: 337-361. DOI: 10.1191/0309133305pp452ra.

Snyder, N. P., Wright, S., A., Alpers, S. N., Flint, L. E., Holmes, C. W. ¿ Rubin, D. M. (2006): Reconstructing depositional processes and history from reservoir stratigraphy: Englebright Lake, Yuba River, northern California. - J. Geophys, Res., 111: F04003. DOI: 10.1029/2005JF000451.

Siegenthaler, C. ¿ Sturm, M. (1991): Die Häufigkeit von Ablagerungen extremer Reuss-Hochwasser: Die Sedimentationsgeschichte im Urnersee seit dem Mittelalter. - Mitteilungen Bundesamt für Wasserwirtschaft, 4: 127-139.

Støren, E. N., Dahl, S. O., Nesje, A. \& PaAsche, Ø. (2010): Identifying the sedimentary imprint of high-frequency Holocene river floods in lake sediments: development and application of a new method. - Quaternary Science Reviews, 29: 3021-3033. DOI:10.1016/j.quascirev.2010.06.038.

Sturm, M. \& MATTER, A (1978): Turbidites and varves in Lake Brienz (Switzerland): Deposition of clastic detritus by density currents. - Specia Publications International Association of Sedimentologists, 2: 147-178.

Swierczynski, T., Lauterbach, S., Dulski, P. \& Brauer, A. (2009): Die Sedimentablagerungen des Mondsees (Oberösterreich) als ein Archiv extremer Abflussereignisse der letzten 100 Jahre. - In: Sснмidt, R., Matulla, C. \& Psenner, R. (eds.): Klimawandel in Österreich - Die letzten 2000 Jahre und ein Blick voraus. - Alpine Space - Man \& Environment, 6: 115-126.

Thorndycraft, V., Hu, Y., Oldfield, F., Crooks, P. R. J. \& Appleby, P. G. (1998): Individual flood events detected in the recent sediments of the Petit Lac d'Annecy, eastern France. - The Holocene, 8: 741-746. DOI: 10.1191/095968398668590504.

Thorndycraft, V. R., Benito, G., Barriendos, M. \& Llasat, M. C. (2003) Palaeofloods, Historical Floods \& Climatic Variability: Applications in Flood Risk Assestment. - In: Thorndycraft, V. R., Benito, G., Barriendos, M. \& Llasat, M. C. (eds.): Palaeofloods, Historical Floods \& Climatic Variability: Applications in Flood Risk Assestment. - Proceedings of the PHEFRA Workshop Barcelona, 16-19th October 2002: 4-9; Madrid.

WeIRICH, F. H. (1986): A Study of the Nature and Incidence of Density Currents in a Shallow Glacial Lake. - Annals of the Association of American Geographers, 76(3): 396-413. 